\title{
LITERASI KEUANGAN SYARIAH DAN PONDOK PESANTREN (STUDI KASUS PONDOK MODERN ASY-SYIFA BALIKPAPAN)
}

\author{
Muhammad Khozin Ahyar \\ Fakultas Ekonomi, Universitas Islam Indonesia Yogyakarta \\ E-mail: khozinahyar@gmail.com
}

\begin{abstract}
Islamic Financial and Islamic Boarding School Literacy (Case study at Modern Islamic Boarding School Asy-Syifa Balikpapan). This study aims to determine the understanding or the Islamic banking literacy among teachers councils of Pondok Modern Ash-Shifa Balikpapan. Besides, the reason for selecting the board of teachers in the use of banking products and services also been discussed in this study. The lack of use of the products and services of Islamic banking among teachers councils of Pondok Modern Ash-Shifa is the focus of the problem in this research. Boarding school as a religious institution to study various classical and contemporary books, especially those related fiqh muamalah is an institution that has an important role in providing Islamic financial literacy for the community. Boarding charismatic cleric is one of the most important figures to provide insight to the public about Islamic banking. However, in reality Pondok Modern Balikpapan Ash-Shifa is not like that. The research method used by writer is a qualitative research survey data collection techniques and interviews. The survey states that 50 members of the council of teachers surveyed, only 16 members of the board of teachers who use Islamic banking products. Furthermore the survey stated that the entire board teachers are customers of savings products sharia. The results of the interview proved that literacy on Islamic banking in Pondok Modern Ash-Shifa Balikpapan still low (less literate). Low literacy Islamic banking is due to lack of socialization and education more depth to the board of teachers Pondok Modern Ash-Shifa.
\end{abstract}

Keywords: financial literacy, Islamic banking, Islamic boarding schools

Abstrak. Literasi Keuangan Syariah dan Pondok Pesantren (Studi Kasus Pondok Modern Asy-Syifa Balikpapan). Penelitian ini bertujuan untuk mengetahui pemahaman atau literasi perbankan syariah di kalangan dewan guru Pondok Modern Ash-Shifa Balikpapan. Selain itu, alasan untuk memilih dewan guru dalam penggunaan produk dan layanan perbankan juga telah dibahas dalam penelitian ini. Kurangnya penggunaan produk dan layanan perbankan Islam di kalangan dewan guru Pondok Modern Ash-Shifa adalah fokus masalah dalam penelitian ini. Pesantren sebagai lembaga keagamaan untuk mempelajari berbagai buku klasik dan kontemporer, terutama yang terkait fiqh muamalah adalah lembaga yang memiliki peran penting dalam memberikan literasi keuangan Islam bagi masyarakat. Membajak ulama kharismatik adalah salah satu tokoh terpenting untuk memberikan wawasan kepada masyarakat tentang perbankan Islam. Namun, kenyataannya Pondok Modern Balikpapan Ash-Shifa tidak seperti itu. Metode penelitian yang digunakan oleh penulis adalah teknik pengumpulan data survey penelitian kualitatif dan wawancara. Survei 
Islamiconomic: Jurnal Ekonomi Islam Vol.9 No.2 Juli - Desember 2018

tersebut menyatakan bahwa 50 anggota dewan guru yang disurvei, hanya 16 anggota dewan guru yang menggunakan produk perbankan syariah. Selanjutnya survei menyatakan bahwa seluruh pengurus dewan adalah pelanggan produk tabungan syariah. Hasil wawancara membuktikan bahwa literasi perbankan Islam di Pondok Modern Ash-Shifa Balikpapan masih rendah (kurang melek huruf). Rendahnya literasi perbankan Islam adalah karena kurangnya sosialisasi dan pendidikan yang lebih mendalam kepada dewan guru Pondok Modern Ash-Shifa.

Kata Kunci: Literasi Keuangan, Perbankan Syariah, Pesantren

\section{PENDAHULUAN}

Menurut para ahli, literasi keuangan merupakan sebuah proses serta kegiatan dalam rangka meningkatkan pengetahuan, kesadaran, keyakinan, kemampuan dan keterampilan mengelola keuangan, sehingga masyarakat dapat memanfaatkan layanan jasa keuangan demi mensejahterakan dan mewaspadai keadaan atau kondisi keuangan di masa yang akan datang (OJK, 2014; Irfan \& Laily, 2016: 224; Giesler \& Veresiu, 2014; Oman \& Lilis, 2014: 23; Dwitya, 2016: 3). Berdasarkan survei yang dilakukan oleh OJK pada tahun 2013 menyatakan bahwa semakin tinggi tingkat pendidikan, maka semakin tinggi juga tingkat pemahaman atau literasi keuangan seseorang. Dalam mengukur tingkat literasi keuangan, terdapat empat tingkatan yang dapat dipakai sebagai tolok ukur, yaitu well literate, sufficient literate, less literate dan not literate.

Survei yang dikeluarkan oleh OJK pada tahun 2013 ini dilakukan masih secara umum, tidak mennunjukkan secara khusus pada keuangan syariah. Padahal, keuangan syariah memiliki spesifikasi khusus yang berbeda dengan keuangan pada umumnya yang bersistem konvensional khususnya pada sisi akad, karena akad akan berpengaruh pada sistem dari suatu produk atau jasa keuangan tersebut.

Perkembangan market share perbankan syariah belakangan ini terlihat melambat. Hal tersebut dapat dipicu oleh berbagai hal, antara lain kondisi ekonomi yang masih belum stabil, akses yang masih tidak terjangkau, harga yang masih mahal dibandingkan konvensional atau kurangnya pemahaman masyarakat tentang perbankan syariah. sampai pada tahun 2017 ini market share perbaankan syariah masih berada di angka 5,3\% (www.infobanknews.com/diakses pada 12 Oktober 2016). Perbankan syariah dapat berkembang lebih cepat apabila terus didukung oleh pemerintah serta lembaga/instansi yang memiliki potensi besar dalam menggunakan produk perbankan syariah. Salah satu lembaga/instansi yang memiliki potensi besar 
Muhammad Khozin. A: Literasi Keuangan Syariah...

$\overline{\text { dalam menggunakan produk perbankan syariah adalah pondok pesantren. Jumlah }}$ pondok pesantren di Indonesia pada tahun 2012 sebanyak 27.230 buah dengan jumlah santri sebanyak kurang lebih 3 juta santri (www.republika.co.id/diakses pada 10 Oktober 2016). Jumlah ini merupakan jumlah yang fantastis jika diperuntukkan bagi sebuah potensi pengembangan dan peningkatan market share perbankan syariah.

Studi kasus pada dewan guru Pondok Modern Asy-Syifa Balikpapan dipilih sebagai objek penelitian dikarenakan minimnya penggunaan produk perbankan syariah di lingkungan tersebut. Berdasarkan observasi peneliti, dari 50 anggota dewan guru, hanya 16 anggota dewang guru yang menggunakan produk perbankan syariah. Disamping itu, Pondok Modern Asy-Syifa Balikpapan memiliki tempat yang strategis untuk pengembangan ekonomi, sehingga nantinya perbankan syariah bisa ikut andil dalam mendorong perekonomian di lingkungan sekitar pondok pesantren. Penelitian ini mendiskusikan tentang tingkat literasi keuangan syariah di kalangan dewan guru Pondok Modern Asy-Syifa Balikpapan. Literasi keuangan syariah yang dibahas dalam penelitian ini lebih mengarah pada pengetahuan tentang perbankan syariah serta penggunaan produk perbankan syariah. Aspek-aspek yang dibahas dalam penelitian ini adalah aspek pengetahuan, keyakinan dan proses/aktivitas.

\section{PEMBAHASAN}

\section{Literasi Keuangan Syariah}

Salah satu langkah awal yang dapat dilakukan untuk meningkatkan market share keuangan syariah, khususnya perbankan syariah adalah dengan melakukan edukasi keuangan syariah kepada masyarakat serta elemen atau tokoh-tokoh penting di masyarakat. Sehingga nantinya akan meningkatkan literasi keuangan syariah, khususnya di bidang perbankan syariah.

Agar dapat meningkatkan literasi keuangan, maka diperlukan adanya edukasi keuangan yang baik. Hogarth dkk. (2003) dalam Ekonomi Pembangunan Syariah mengatakan bahwa proses edukasi keuangan dianggap metode paling efektif untuk meningkatkan literasi keuangan terhadap masyarakat (Irfan \& Laily, 2016: 223), termasuk literasi keuangan syariah. 
OJK (2014) mendefinisikan literasi keuangan sebagai rangkaian proses atau aktivitas untuk meningkatkan pengetahuan (knowledge), keyakinan (competence) dan keterampilan (skill) konsumen dan masyarakat luas sehingga mereka mampu mengelola keuangan dengan lebih baik. Pembahasan yang akan dilakukan pada bagian analisis hasil riset adalah dengan mempertimbangkan hasil penelitian dengan aspek pengetahuan, keyakinan serta proses atau aktivitas dalam memenuhi kriteria literasi keuangan. Terdapat empat tingkatan yang dapat dipakai sebagai tolok ukur, yaitu well literate, sufficient literate, less literate dan not literate. Masing-masing tingkatan tersebut dapat dijelaskan melalui aspek yang terdapat pada tabel berikut:

Tabel 1

Tingkat Literasi Keuangan

\begin{tabular}{|c|c|c|c|c|}
\hline $\begin{array}{c}\text { Kategori } \\
\text { Aspek }\end{array}$ & $\begin{array}{c}\text { Well } \\
\text { Literate }\end{array}$ & $\begin{array}{c}\text { Sufficient } \\
\text { Literate }\end{array}$ & $\begin{array}{c}\text { Less } \\
\text { Literate }\end{array}$ & $\begin{array}{c}\text { Not } \\
\text { Literate }\end{array}$ \\
\hline $\begin{array}{c}\text { Pengetahuan \& Keyakinan tentang } \\
\text { LJK }\end{array}$ & $\mathrm{V}$ & $\mathrm{V}$ & $\mathrm{V}$ & $\mathrm{X}$ \\
\hline $\begin{array}{c}\text { Produk \& Jasa Keuangan } \\
\text { Fitur, Manfaat, Risiko, Hak \& } \\
\text { Kewajiban }\end{array}$ & $\mathrm{V}$ & $\mathrm{V}$ & $\mathrm{V}$ & $\mathrm{X}$ \\
\hline $\begin{array}{c}\text { Keterampilan dalam } \\
\text { menggunakan Produk \& Jasa } \\
\text { Keuangan }\end{array}$ & $\mathrm{V}$ & $\mathrm{V}$ & $\mathrm{X}$ & $\mathrm{X}$ \\
\hline \begin{tabular}{c} 
Veumang \\
\hline
\end{tabular} & $\mathrm{X}$ & $\mathrm{X}$ \\
\hline
\end{tabular}

Sumber: OJK (2014)

Tingkat literasi keuangan syariah yang tinggi dapat mengakibatkan pada meningkatnya penggunaan produk dan jasa keuangan syariah di Indonesia yang secara langsung juga berakibat pada meningkatnya market share keuangan syariah di Indonesia. Dalam jurnal yang berjudul Bridging Islamic Financial Literacy and Halal Literacy: The Way Forward in Halal Ecosystem (Purnomo dkk, 2016: 199) dijelaskan bahwa hal tersebut disebabkan karena literasi keuangan kuat hubungannya dengan keputusan seseorang untuk menggunakan keuangan formal (Xiao, et. al 2014).

Selain hal-hal di atas, edukasi keuangan yang tepat juga akan memberi dampak pada tingkat pemahaman masyarakat terhadap konsep dasar keuangan syariah. Bagaimana konsep akad dalam keuangan syariah, serta perbedaannya dengan transaksi keuangan konvensional, semuanya harus dapat ditransformasikan dengan baik kepada masyarakat. Sehingga, masyarakat dapat mengetahui dengan jelas perbedaannya (Irfan \& Laily, 2016: 222). Perlu disampaikan juga kepada masyarakat terkait bagaimana caranya mengakses lembaga keuangan syariah, termasuk lembaga keuangan mikro syariah. Dengan pendekatan yang bersifat komprehensif, maka 194 
Muhammad Khozin. A: Literasi Keuangan Syariah...

diharapkan tingkat kesadaran dan partisipasi publik terhadap institusi keuangan syariah dapat meningkat dari waktu ke waktu (Irfan \& Laily, 2016: 222).

\section{Keuangan Syariah}

Keuangan syariah merupakan lembaga-lembaga yang melayani produk dan jasa keuangan berbasis prinsip syariah, seperti Perbankan Syariah, Asuransi Syariah, Pegadaian Syariah, Pasar Modal Syariah, Dana Pensiun Syariah dan Lembaga Pembiayaan Syariah. Dalam pembahasan artikel ini, penulis lebih konsentrasi kepada Perbankan Syariah. Aktivitas Keuangan Islam biasanya diatur oleh Bank Islam. Bank Islam merupakan bagian dari Keuangan Islam. Bank Islam ini merupakan Bank yang berdasarkan pada syariah (hukum Islam) yang biasa disebut fiqh muamalah (aturan Islam dalam melakukan transaksi). Aturan dan regulasi fiqh muamalah berasal dari Al-Qur'an dan Sunnah. Disamping itu, aturan dan regulasi fiqh muamalah juga bisa berdasarkan pada sumber-sumber hukum Islam yang lain, seperti ijma', qiyas dan ijtihad (Purnomo et al., 2016).

Prinsip yang mendasari Keuangan Islam, antara lain larangan terhadap riba (bunga/interest), larangan terhadap maysir (judi/gambling) dan larangan terhadap gharar (ketidakpastian). Prinsip lainnya yang juga mendasari Keuangan Islam adalah penggunaan serta transaksi beberapa komoditas yang terlarang atau haram dalam Islam. Dalam terminologi Keuangan Islam, banyak istilah-istilah metode yang biasa digunakan, seperti mudharabah, musyarakah, murabahah, istishna', salam, ijarah dan qardhul hasan (Purnomo et al., 2016).

Menurut Undang-Undang Nomor 21 Tahun 2008 Tentang Perbankan Syariah, perbankan syariah adalah segala sesuatu yang berhubungan dengan Bank Umum Syariah dan Unit Usaha Syariah, mencakup lembaga, kegiatan usaha, serta cara dan proses dalam melaksanakan kegiatan usahanya. Bank Umum Syariah adalah Bank Syariah yang dalam menjalankan kegiatan usahanya memberikan jasa dalam lalu lintas pembayaran. Unit Usaha Syariah merupakan unit kerja dari kantor pusat Bank Umum Konvensional yang berfungsi sebagai kantor induk atau unit yang melaksanakan kegiatan usahanya berdasarkan prinsip syariah.

Bank Syariah menurut UU No. 21 Tahun 2008 adalah Bank yang menjalankan kegiatan usahanya berdasarkan prinsip syariah dan menurut jenisnya terdiri atas 
Islamiconomic: Jurnal Ekonomi Islam Vol.9 No.2 Juli - Desember 2018

$\overline{\text { Bank Umum Syariah dan Bank Pembiayaan Rakyat Syariah. Bank Pembiayaan Rakyat }}$ Syariah adalah Bank Syariah yang dalam kegiatannya tidak memberikan jasa dalam lalu lintas pembayaran.

Secara garis besar, Bank Syariah terdiri dari 3 (tiga) macam produk, yaitu Produk Pendanaan, Produk Pembiayaan dan Produk Jasa (Ascarya, 2012: 112). Produk pendanaan Bank Syariah ditujukan untuk mobilisasi dan investasi tabungan untuk pembangunan perekonomian dengan cara yang adil sehingga keuntungan yang adil dapat dijamin bagi semua pihak. Bank Syariah pada umumnya memiliki tiga produk pendanaan dengan menggunakan berbagai macam akad yang berbeda dengan Bank Konvensional, yaitu giro, tabungan dan deposito.

Tabel 2

Produk dan Akad Funding Bank Syariah

\begin{tabular}{|l|c|c|}
\hline & Wadi'ah & Mudharabah \\
\hline Giro & $\mathrm{V}$ & $\mathrm{V}$ \\
\hline Tabungan & $\mathrm{V}$ & $\mathrm{V}$ \\
\hline Deposito & & $\mathrm{V}$ \\
\hline
\end{tabular}

Sumber: Ascarya (2012), Produk \& Akad Bank Syariah

Produk yang selanjutnya, yaitu produk pembiayaan. Produk pembiayaan bank syariah berdasarkan penggunaannya, dapat dikategorikan ke dalam dua macam, yakni pembiayaan produktif dan pembiayaan konsumtif. Berdasarkan akadnya, produk pembiayaan bank syariah dapat dikategorikan ke dalam tiga macam, yakni pembiayaan berbasis jual-beli, pembiayaan berbasis bagi hasil dan pembiayaan berbasis sewa. 
Muhammad Khozin. A: Literasi Keuangan Syariah...

Tabel 3

Produk \& Akad Pembiayaan Bank Syariah

\begin{tabular}{|c|c|c|c|}
\hline $\begin{array}{c}\text { Akad \& Konsep } \\
\text { Pembiayaan }\end{array}$ & Jual Beli & Bagi Hasil & Sewa \\
\hline Murabahah & $\mathrm{V}$ & $\mathrm{X}$ & $\mathrm{X}$ \\
\hline Salam & $\mathrm{V}$ & $\mathrm{X}$ & $\mathrm{X}$ \\
\hline Istishna' & $\mathrm{V}$ & $\mathrm{X}$ & $\mathrm{X}$ \\
\hline Mudharabah & $\mathrm{X}$ & $\mathrm{V}$ & $\mathrm{X}$ \\
\hline Musyarakah & $\mathrm{X}$ & $\mathrm{V}$ & $\mathrm{V}$ \\
\hline MMQ & $\mathrm{X}$ & $\mathrm{X}$ & $\mathrm{V}$ \\
\hline Ijarah & $\mathrm{X}$ & $\mathrm{X}$ & $\mathrm{X}$ \\
\hline IMBT & $\mathrm{X}$ & $\mathrm{V}$ & \\
\hline
\end{tabular}

Sumber: Ascarya (2012), Produk \& Akad Bank Syariah

Produk selanjutnya yang terdapat pada bank syariah adalah jasa (fee-based service). Produk jasa pada bank syariah, pada umumnya terdiri dari bank garansi, jual beli valuta asing, transfer, anjak piutang, RTGS, L/C, gadai, kliring, inkaso dan lain sebagainya. Dari sisi akad yang digunakan, jasa pada bank syariah umumnya menggunakan akad wadi'ah, hiwalah, wakalah, kafalah, sharf serta rahn.

Tabel 4

Produk dan Akad Jasa Bank Syariah

\begin{tabular}{|l|l|}
\hline \multicolumn{1}{|c|}{ Produk } & \multicolumn{1}{c|}{ Akad } \\
\hline Transfer & Wakalah \\
\hline Kliring & Wakalah \\
\hline Inkaso & Wakalah \\
\hline RTGS & Wakalah \\
\hline Letter of Credit (L/C) & Wakalah \\
\hline Anjak Piutang & Hiwalah \\
\hline Jual beli valuta asing & Sharf \\
\hline Gadai & Rahn \\
\hline Bank Garansi & Kafalah \\
\hline Safe Deposit Box & $\begin{array}{l}\text { Wadi'ah yad } \\
\text { amanah }\end{array}$ \\
\hline
\end{tabular}

Sumber: Ascarya (2012), Produk \& Akad Bank Syariah 


\section{Pondok Pesantren}

Pesantren merupakan lembaga pendidikan Islam paling awal di Indonesia. Pesantren, gerakan pembaruan Islam dan sistem pendidikan Belanda merupakan tiga faktor penting yang secara bersama-sama menyediakan sebuah environment bagi kemunculan sebuah madrasah modern Indonesia (Arief, 2012: 73). Pesantren, lembaga pendidikan tradisional, merupakan basis penyebaran sistem pendidikan madrasah di Indonesia. Gerakan pembaruan Islam merupakan jembatan yang menjadi transmisi gagasan modern dalam pengelolaan pendidikan Islam yang berasal dari Timur Tengah. Sistem pendidikan Belanda merupakan inspirator dan kompetitor umat muslim di Indonesia dalam mengembangkan sistem pendidikan Islam (Arief, 2012: 73-74).

Secara terminologis, pendidikan pesantren dapat dilihat dari segi bentuk dan sistemnya yang berasal dari India. Sebelum proses penyebaran Islam di Indonesia, sistem tersebut telah dipergunakan secara umum untuk pendidikan dan pengajaran agam Hindu di Jawa (Karel, 1991: 20). Pesantren dapat diartikan sebagai lembaga pendidikan Islam yang menyediakan asrama atau tempat tinggal bagi santrinya untuk belajar. Pada masa sekarang, terdapat dua jenis pondok pesantren, yaitu pondok pesantren salafi (tradisional) dan pondok modern.

Pondok pesantren salafi merupakan jenis pesantren yang tetap mempertahankan pengajaran kitab-kitab Islam klasik sebagai inti dari pendidikan, sedangkan pelajaran umum tidak diajarkan. Pada umumnya pesantren jenis ini menggunakan sistem sorogan dan weton (Yasmadi, 2002: 70). Pondok modern merupakan pondok pesantren yang telah merubah sistem pembelajarannya dari tradisional menjadi lebih modern. Pondok modern memiliki sistem pembelajaran yang sistematik dan memberikan porsi yang besar terhadap pelajaran umum. Pembelajaran dilakukan di dalam kelas, sama halnya seperti sekolah atau madrasah formal baik negeri maupun swasta yang lain. Referensi utama dalam pelajaran keislaman bukan kitab kuning atau klasik, melainkan kitab-kitab baru yang ditulis oleh para ilmuwan muslim pada abad ke-20 (Arief, 2012: 129).

Berbeda dengan pesantren salafi, pondok modern memiliki ciri-ciri yang menjadi khas dari sebuah pondok modern. Ciri khas pondok modern yang pertama yaitu tekanan yang sangat kuat terhadap pembelajaran bahasa Arab dan Inggris. Ciri 
Muhammad Khozin. A: Literasi Keuangan Syariah...

khas yang kedua yaitu penekanan terhadap aspek kedisiplinan dalam segala aktifitas sehari-hari (Arief, 2012: 130). Masih banyak ciri lain yang menunjukkan kekhasan pada pondok modern.

\section{METODOLOGI}

Pada artikel ini, peneliti menggunakan metode penelitian kualitaif. Penelitian kualitatif merupakan suatu strategi inquiry yang menekankan pencarian makna, pengertian, konsep, karakteristik, gejala, simbol, maupun diskripsi tentang suatu fenomena; fokus dan multimetode; bersifat alami dan holistik; mengutamakan kualitas, menggunakan beberapa cara, serta disajikan secara naratif. Secara sederhana, tujuan penelitian kualitatif adalah untuk menemukan jawaban terhadap suatu fenomena atau pertanyaan melalui aplikasi prosedur ilmiah secara sistematis dengan menggunakan pendekatan kualitatif (Muri, 2014: 329).

Teknik pengumpulan data yang digunakan oleh penulis dalam penelitian ini adalah survei, observasi, wawancara, audio dan visual. Survei dilakukan kepada 50 anggota dewan guru di Pondok Modern Asy-Syifa Balikpapan. Hasil survey digunakan untuk memberikan fakta dalam penulisan bahwa dewan guru Pondok Modern AsySyifa Balikpapan masih minim dalam menggunakan produk perbankan syariah. Observasi dilakukan penulis dengan berkunjung langsung kepada salah satu pengurus koperasi guru. Hasil observasi juga digunakan penulis sebagai bahan temuan fakta di lapangan terkait kondisi literasi keuangan syariah di kalangan dewan guru Pondok Modern Asy-Syifa Balikpapan. Hasil dari observasi penulis dapat memperkuat hasil wawancara dengan beberapa dewan guru. Peneliti mengamati aktivitas perekonomian yang berada di sekitar lingkungan pondok pesantren. Disamping itu, peneliti juga mengamati rekening yang digunakan oleh pondok pesantren dalam menyimpan atau mengelolan dana yang dimilikinya. Peneliti tidak hanya mengamati, akan tetapi peneliti juga merekam aktivitas yang dilakukan oleh dewan guru agar hasil observasi dapat dipertanggungjawabkan. Perekaman berupa tulisan/catatan lapangan dengan menggunakan form catatan observasi.

Wawancara dilakukan secara individu atau face to face. Wawancara dengan model seperti ini dilakukan karena jadwal mengajar setiap guru berbeda antara satu dengan yang lain. Disamping itu, peneliti juga melakukan wawancara melalui media 
Islamiconomic: Jurnal Ekonomi Islam Vol.9 No.2 Juli - Desember 2018

komunikasi lain seperti telpon, whats app dan lain sebagainya. Peneliti mengajukan pertanyaan yang sama dan berkaitan dengan tema kepada seluruh responden wawancara. Terdapat dua model pertanyaan yang akan diajukan, yaitu pertanyaan yang terstrukur dan tidak terstruktur. Pertanyaan terstruktur merupakan pertanyaan yang telah disiapkan oleh peneliti, sedangkan tidak terstruktur muncul secara spontan ketika wawancara sebagai pendalaman terhadap jawaban responden.

Teknik pengumpulan data yang terakhir yaitu audio dan visual. Pada teknik ini, peneliti melakukan perekaman dengan menggunakan kamera atau taperecorder untuk merekam hasil wawancara, sehingga peneliti tidak hanya terpaku pada tulisan atau catatan. Hasil rekaman wawancara ini bisa dimanfaatkan oleh peneliti untuk melakukan recheck terhadap jawaban-jawaban atas pertanyaan yang diajukan. Sehingga dapat membantu peneliti dalam menganalisis jawaban serta memperkuat keabsahan data yang menjadi bahan penelitian.

\section{HASIL PENELITIAN}

\section{Aspek Pengetahuan}

Pengetahuan yang dimaksud dalam pembahasan literasi keuangan ini adalah mengenai lembaga jasa keuangan, produk dan/atau layanan jasa keuangan (POJK Literasi dan Inklusi Keuangan). Dalam pembahasan ini termasuk didalamnya adalah akad yang digunakan dalam produk perbankan syariah.

Pengetahuan informan tentang perbankan syariah masih belum terlalu luas. Produk-produk perbankan syariah yang bervariasi tidak dimengerti secara mendalam oleh informan. Padahal banyak keuntungan atau kelebihan serta kemudahan yang bisa diperoleh dari produk perbankan syariah yang lainnya. Informan pertama menyatakan bahwa kegiatan pemasukan (pendanaan) di perbankan syariah itu semuanya syariah. Namun ketika melakukan pengeluaran (pembiayaan) itu semuanya tidak syariah kecuali Bank Muamalat. Padahal kenyataannya, kegiatan pendanaan dan pembiayaan di perbankan syariah sama saja. Kesamaan tersebut karena semua perbankan syariah memiliki regulasi serta aturan atau payung hukum yang sama.

Seluruh produk yang ada di perbankan syariah pada umumnya memiliki payung hukum tersendiri, yaitu UU No. 21 Tahun 2008 tentang Perbankan Syariah kemudian 
Muhammad Khozin. A: Literasi Keuangan Syariah...

diperkuat lagi dengan Fatwa Dewan Syariah Nasional MUI. Disamping itu, payung hukum itu kemudian juga diperkuat lagi dengan adanya POJK (Peraturan Otoritas Jasa Keuangan) dan PBI (Peraturan Bank Indonesia) sebagai bentuk pengaturan, pengawasan serta perlindungan terhadap konsumen. Regulasi atau payung hukum yang sama merupakan keselarasan atau penyeragaman produk di seluruh perbankan syariah Indonesia. Hanya saja, variasi produk, kemudahan akses dan pendekatan kepada para nasabah yang berbeda antara perbankan syariah di Indonesia.

Para informan wawancara belum banyak mengetahui soal produk-produk yang berada di perbankan syariah, termasuk juga akad-akad yang digunakan. Para informan hanya mengetahui sebatas produk yang mereka gunakan. Walaupun mereka menggunakan produk tersebut, informan masih belum memahami $100 \%$ soal produk tersebut serta akadnya. Informan hanya menggunakan produk perbankan syariah yang sesuai dengan kebutuhan informan, begitupun dengan dewan guru lainnya yang menggunakan produk perbankan syariah. Hal tersebut juga sejalan dengan hasil penelitian yang dilakukan oleh Amena \& Wahyu (2014: 422) yang menyatakan bahwa masyarakat hanya mengenal dan memahami produk dan jasa keuangan yang mereka gunakan saja. Berdasarkan hasil survei yang penulis lakukan, dewan guru Pondok Modern Asy-Syifa Balikpapan masih minim dalam menggunakan produk Perbankan Syariah (lihat tabel 5). Dari 16 anggota dewan guru yang menggunakan produk perbankan syariah, seluruhnya merupakan nasabah tabungan di perbankan syariah.

Tabel 5

Dewan Guru Nasabah Perbankan Syariah

\begin{tabular}{|c|c|}
\hline $\begin{array}{c}\text { Nasabah } \\
\text { Perbankan } \\
\text { Syariah }\end{array}$ & $\begin{array}{c}\text { Non } \\
\text { Nasabah } \\
\text { Perbankan } \\
\text { Syariah }\end{array}$ \\
\hline 16 & 34 \\
\hline
\end{tabular}

Sumber: Data diolah

Lebih rinci, penulis memberikan pertanyaan lanjutan dalam survei kepada dewan guru yang merupakan nasabah perbankan syariah terkait akad yang digunakan. Adapun rincian hasil survei tersebut dapat dilihat pada tabel 6 berikut ini. 
Islamiconomic: Jurnal Ekonomi Islam

Vol.9 No.2 Juli - Desember 2018

Tabel 6

Akad yang Digunakan oleh Dewan Guru Nasabah Perbankan Syariah

\begin{tabular}{|c|c|c|c|}
\hline \multicolumn{4}{|c|}{ Akad Produk PBS yg digunakan } \\
\hline $\begin{array}{c}\text { Wadiah } \\
\text { dhamanah }\end{array}$ & $\begin{array}{c}\text { Wadiah } \\
\text { amanah }\end{array}$ & $\begin{array}{c}\text { Mudharabah } \\
\text { muthlaqah }\end{array}$ & $\begin{array}{c}\text { Mudharabah } \\
\text { Muqayyadah }\end{array}$ \\
\hline 9 & 4 & 2 & 1 \\
\hline
\end{tabular}

Sumber: Data Diolah

Berdasarkan tabel 6 diatas, jika diperhatikan terdapat suatu hal yang negatif. Pada umumnya, tabungan pada produk perbankan syariah di Indonesia menggunakan dua akad, yaitu wadiah yad dhmanah (Syafi'i, 2015: 149) dan mudharabah muthlaqah (Ascarya, 2012:117). Namun, pada tabel tersebut terlihat sebagian anggota dewan guru nasabah perbankan syariah menjawab akad mudharabah muqayyadah dan wadiah amanah. Akad wadiah amanah pada umumnya digunakan untuk produk titipan murni, seperti produk Safe Deposit Box (SDB). Safe Deposit Box ini merupakan produk penitipan barang/aset berharga nasabah, seperti surat/sertifikat tanah, emas batangan dan lain sebagainya. Sedangkan, akad mudharabah muqayyadah merupakan akad yang pada umumnya digunakan untuk berinvestasi, dalam perbankan syariah pada umumnya digunakan pada produk deposito (Syafi'i, 2015: 148). Berdasarkan hasil penelitian dan pembahasan yang telah dilakukan, dapat dikatakan bahwa pengetahuan dewan guru Pondok Modern Asy-Syifa tentang Perbankan Syariah tergolong less literate. Tergolong ke dalam less literate karena sebagian dewan guru hanya mengerti terhadap produk perbankan syariah yang digunakan.

\section{Aspek Keyakinan}

Keyakinan yang dimaksud dalam literasi keuangan adalah kepercayaan seseorang terhadap suatu lembaga jasa keuangan maupun produk dan jasa keuangan, sehingga diharapkan seluruh masyarakat Indonesia dapat menggunakan produk dan/atau layanan jasa keuangan yang sesuai dengan kebutuhan dan kemampuan (POJK Literasi dan Inklusi Keuangan). Dalam hal pembahasan ini, lembaga yang dimaksud adalah perbankan syariah. 
Muhammad Khozin. A: Literasi Keuangan Syariah...

Keyakinan informan dari sudut pandang syariah, kedua-duanya masih ragu soal kesyariahan produk di perbankan syariah. Informan pertama menyatakan dengan nada bicara yang sedikit tinggi bahwa keraguannya terhadap kesyariahan produk di perbankan syariah disebabkan oleh nilai keuntungan yang ingin diambil oleh perbankan syariah sama dengan besaran keuntungan yang ingin diambil oleh perbankan konvensional. Disamping itu juga, angsuran yang tidak boleh dipercepat penyelesaiannya juga alasan informan masih ragu dengan produk di perbankan syariah.

"Saya ragu-ragu. Sekarang begini, kita pernah waktu itu mengajukan peminjaman untuk bayar utang rumah. Dulu itu kita coba ke konvensional juga hitungannya sama. Peminjaman setahun waktu itu 150 juta, bayarnya setahun 20 juta tambahan bunganya. Kalau di bank syariah bahasa mereka murabahah. Mereka mengatakan kurang lebih 20 juta juga tambahannya daripada utang bayaran selama setahun cicilannya, artinya saya kan ragu bahasanya (pertama). Kedua, saya pernah beli rumah, masih utang. Waktu itu pertama kali perumahan yang di kilo 9 itu di bank konvensional, lalu dialihkan ke bank syariah. Waktu itu saya mengajukan, boleh tidak saya minta yang 10 tahun jadi 5 tahun? Dari pihak bank mengatakan tidak boleh" (wawancara pada tanggal 25 April 2017 di ruang guru MI).

Perbankan syariah selalu mempertimbangkan perencanaan keuangan yang sudah dilakukan baik dari sisi pos pemasukan maupun pos pengeluaran (ToT Aplikasi Salam BRIS). Disamping itu, aspek kemampuan nasabah dalam membayar angsuran juga merupakan hal yang masuk ke dalam pertimbangan ketika hendak menyalurkan dana pembiayaan (Muhammad, 2004: 86). Kegagalan nasabah dalam membayar angsuran dapat merubah sedikit banyaknya perencanaan keuangan yang sudah disusun. Pengambilan keuntungan (marjin) yang ingin diambil oleh perbankan syariah sebenarnya juga menggunakan beberapa pertimbangan atau referensi. Menurut Adiwarman (2014: 280), terdapat 5 referensi yang dijadikan sebagai rujukan atau pertimbangan perbankan syariah dalam menentukan marjin, yaitu Direct Competitor's Market Rate (DCMR), Indirect Competitor's Market Rate (ICMR), Expected Competitive Return for Investors, Acquiring Cost dan Overhead Cost.

Berbeda dengan informan pertama, informan kedua menjelaskan bahwa keraguan disebabkan oleh beberapa transaksi yang harus menggunakan sistem konvensional, karena belum ada jalan yang sesuai syariah. Sehingga terpaksa harus 
Islamiconomic: Jurnal Ekonomi Islam

Vol.9 No.2 Juli - Desember 2018

menggunakan transaksi yang masih bersistem konvensional tersebut.Walaupun informan yang kedua ini sedikit kurang meyakini soal kesyariahan produk di perbankan syariah, namun informan masih menyadari bahwa sebagai seorang muslim, informan harus mencari jalur yang sesuai syariah termasuk gaya hidup atau life style.

"Karena saya seorang muslim, saya harus mencari jalur yang sesuai dengan syariat" (wawancara pada tanggal 27 April 2017 di kediaman KH. Abdurrahman Hasan).

Keragu-raguan yang timbul pada dewan guru terkait kesyariahan produk di perbankan syariah seharusnya sudah tidak perlu dikhawatirkan lagi, karena di Indonesia melalui MUI telah membentuk suatu lembaga yang berdiri pada tahun 1997 yang berfungsi untuk mengawasi kesyariahan suatu produk di lembaga keuangan syariah, termasuk perbankan syariah. Lembaga tersebut adalah Dewan Syariah Nasional (DSN). Dewan Syariah Nasional dapat memberi teguran kepada lembaga keuangan syariah jika lembaga tersebut menyimpang dari garis panduan yang telah ditetapkan (Syafi'i, 2015: 32). Berdasarkan hasil penelitian dan pembahasan yang sudah dilakukan, keyakinan dewan guru Pondok Modern Asy-Syifa dapat digolongkan kepada kategori rendah. Rendahnya keyakinan dewan guru tersebut merupakan akibat dari minimnya pengetahuan tentang perbankan syariah.

\section{Aspek Proses/Aktivitas}

Berdasarkan hasil wawancara dengan informan, mereka menyatakan serta mengakui bahwa belum ada kegiatan sosialisasi dan edukasi terkait industri jasa keuangan khususnya perbankan syariah baik secara langsung maupun tidak langsung. Namun, informan pertama mengakui bahwa ada beberapa brand perbankan syariah yang pernah datang untuk menawarkan berbagai layanan produk dan jasa yang dimiliki oleh bank syariah tersebut.

"Belum ada, tapi kalau pengajuan yang kaya BRI Syariah, Bank Mandiri Syariah pernah datang kesini berkali-kali, baik masalah perumahan, baik masalah buka rekening. Tapi kalau masalah yang sosialisasi tadi dan macam-macam itu tidak. Yang ada yang tadi aja buka rekening, cara mudah co branding tadi, kemudian masalah perumahan misalnya secara syariah pembayarannya ada juga kaya begitu. Tapi kalau masalah yang itu tidak" (wawancara pada tanggal 25 April 2017 di ruang guru MI). 
Muhammad Khozin. A: Literasi Keuangan Syariah...

Sejalan dengan hasil wawancara informan diatas, hasil survei terhadap dewan guru juga menyatakan bahwa kurangnya sosialisasi tentang perbankan syariah kepada dewan guru di Pondok Modern Asy-Syifa (lihat tabel 7).

Tabel 7

Kegiatan Sosialisasi \& Edukasi Perbankan Syariah

\begin{tabular}{|c|c|}
\hline \multicolumn{2}{|c|}{$\begin{array}{c}\text { Mengikuti Kegiatan } \\
\text { Sosialisasi \& Edukasi }\end{array}$} \\
\hline Ya & Tidak \\
\hline 10 & 40 \\
\hline
\end{tabular}

Sumber: Data Diolah

Setiap tahunnya secara rutin Otoritas Jasa Keuangan bekerjasama dengan beberapa lembaga keuangan syariah serta organisasi penggiat ekonomi syariah mengadakan kegiatan atau event dalam rangka mengenalkan lembaga keuangan syariah seperti iB Vaganza, Keuangan Syariah Fair, Training of Trainer, Pesta Rakyat Syariah dan lain sebagainya. Event-event tersebut dilaksanakan oleh OJK hampir di seluruh daerah tingkat Kabupaten/Kota di Indonesia (Materi Sosialisasi Edukasi dan Perlindungan Konsumen, 27 September 2016). Pengenalan keuangan syariah, khususnya perbankan syariah saat ini tidak hanya dilakukan dengan mengadakan event-event atau agenda di tempat umum. Akan tetapi, pengenalan keuangan syariah saat ini sudah dikembangkan seperti melalui media sosial, kunjungan lapangan, pelatihan gratis kepada guru-guru ekonomi dan lain sebagainya. Tidak hanya memberikan sosialisasi kepada masyarakat yang dewasa saja, saat ini 0JK telah melakukan edukasi dan sosialisasi tentang lembaga keuangan sejak dini kepada para pelajar mulai dari SD hingga perguruan tinggi bahkan pondok pesantren. Berbagai kemudahan teknologi dan lainnya harusnya dapat dimanfaatkan oleh dewan guru untuk memperluas wawasan tentang perbankan syariah.

Gambar 1

Sosialisasi Perbankan Syariah di Lingkungan Pondok Pesantren

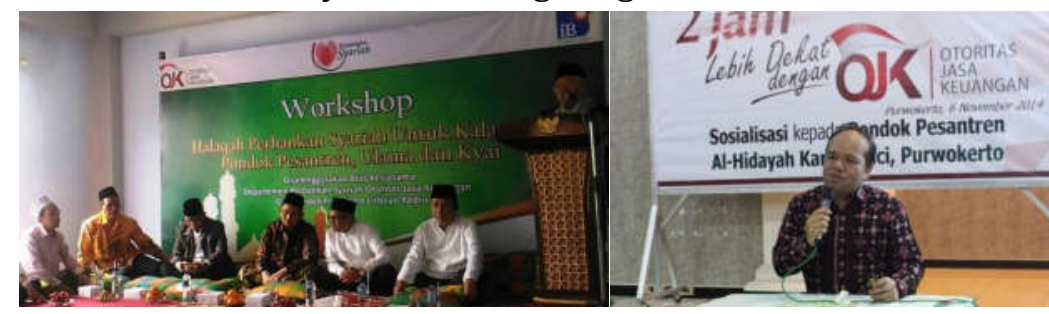

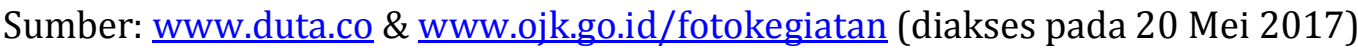


Islamiconomic: Jurnal Ekonomi Islam Vol.9 No.2 Juli - Desember 2018

Pondok pesantren dipilih sebagai target untuk melakukan edukasi dan sosialisasi karena perannya yang sangat penting dalam membangun Inklusi Keuangan dan berpengaruh bagi masyarakat muslim (www.ekbis.sindonews.com/ diakses pada tanggal 20 Mei 2017). Menurut Kepala Kantor OJK Tasikmalaya, Iwan M. Ridwan mengatakan bahwa pesantren dianggap memiliki pengaruh dalam meningkatkan perekonomian syariah (www.koran-sindo.com/ diakses pada tanggal 20 Mei 2017).

\section{Gambar 2}

Situasi Lingkungan Asrama 2012 (Kiri) dan 2017 (Kanan)
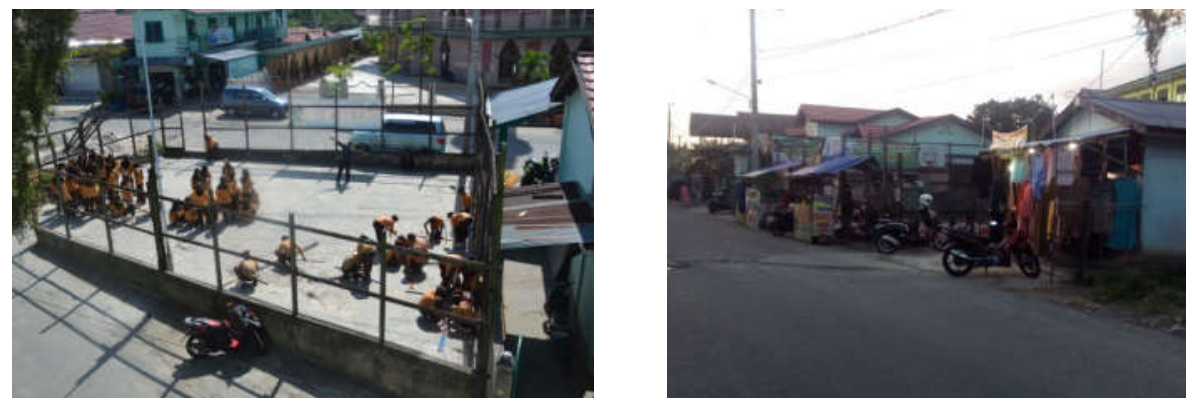

Sumber: Koleksi Peneliti

Pengaruh pondok pesantren terhadap peningkatan serta pertumbuhan ekonomi syariah karena pondok pesantren memiliki ulama yang kharismatik, yang memiliki banyak jamaah dan dekat dengan umat. Sehingga ulama memiliki peran penting dalam mensosialisasikan perbankan syariah. Adapun peran penting tersebut adalah (Syafi'i, 2015: 237):

1. Menjelaskan kepada masyarakat bahwa perbankan syariah pada dasarnya adalah penerapan (tathbiq) fiqh muamalah maaliyah;

2. Mengembalikan masyarakat pada fitrah alam dan fitrah usaha yang sebelumnya telah mengikuti syariah, terutama dalam pertanian, perdagangan, investasi dan perkebunan;

3. Meluruskan fitrah bisnis yang rusak seperti meluasnya ungkapan "cari duit secara haram pun susah, apalagi secara halal";

4. Membantu menyelamatkan perekonomian bangsa melalui pengembangan sosialisasi perbankan syariah.

Keberadaan pondok pesantren di lingkungan masyarakat sangat membantu mengembangkan perekonomian masyarakat sekitar yang berada dekat dengan lingkungan pondok pesantren. Peneliti menemukan bahwa perbandingan situasi 
Muhammad Khozin. A: Literasi Keuangan Syariah...

lingkungan asrama pada tahun 2012 dengan situasi lingkungan asrama pada tahun 2017 sangatlah berbeda (lihat gambar 2).

Berdasarkan hasil observasi peneliti, pada tahun 2012, situasi lingkungan asrama kampus 1 masih belum ada aktivitas usaha yang begitu terlihat. Namun, pada tahun 2017 ketika peneliti melakukan penelitian, situasi berbeda dirasakan oleh peneliti. Situasi yang ramai dengan masyarakat yang membuka usaha bergeliat di lingkungan asrama kampus 1. Hal ini dapat menjadi peluang perbankan syariah untuk mendekatkan akses permodalan kepada para pengusaha UMKM di sekitar lingkungan pesantren dengan menggandeng pondok pesantren sebagai perantaranya.

Berdasarkan gambar 2, kondisi tersebut sejalan dengan pernyataan Lukman Hakim Saifudin dalam wawancaranya yang menyatakan bahwa pondok pesantren memiliki potensi menjadi pusat ekonomi desa (www.bisniskeuangan.kompas.com/ diakses pada tanggal 20 Mei 2017). Pada kesempatan yang lain, Muliaman Hadad menyatakan bahwa pondok pesantren memiliki peran penting dalam meningkatkan inklusi keuangan (www.ekbis.sindonews.com/ diakses pada tanggal 20 Mei 2017).

Pada saat potensi perekonomian itu terlihat, disitulah masyarakat membutuhkan pengetahuan tentang akses permodalan yang mudah, murah dan cepat untuk membangun usaha/bisnis. Disinilah peran penting pondok pesantren sebagai perantara Perbankan Syariah untuk memberikan akses permodalan kepada masyarakat sekitar pondok pesantren, sehingga nantinya akan terwujud upaya pemberdayaan ekonomi berbasis pesantren, dan inklusi keuangan akan tercapai. Agar dapat mencapai itu semua, para ulama atau dewan guru pondok pesantren, khususnya Pondok Modern Asy-Syifa harus memiliki pengetahuan dan wawasan yang luas tentang lembaga keuangan syariah terutama perbankan syariah. Pengetahuan serta wawasan yang luas tentang perbankan syariah akan meningkatkan keyakinan di kalangan dewan guru Pondok Modern Asy-Syifa untuk menggunakan produk dan jasa perbankan syariah.

Namun pada kenyataan yang terjadi di Pondok Modern Asy-Syifa, dewan guru masih memiliki tingkat pengetahuan dan keyakinan yang rendah. Penyebab rendahnya pengetahuan dan keyakinan tersebut jika dilihat dari hasil penelitian dan pembahasan yang telah dilakukan, penyebabnya adalah kurangnya sosialisasi dan edukasi secara mendalam kepada dewan guru Pondok Modern Asy-Syifa. 
Islamiconomic: Jurnal Ekonomi Islam Vol.9 No.2 Juli - Desember 2018

Kurangnya sosialisasi dan edukasi secara mendalam disebabkan oleh kurang dibangunnya komunikasi antara pihak pondok pesantren dengan otoritas terkait yaitu Bank Indonesia dan Otoritas Jasa Keuangan. Bank Indonesia dan Otoritas Jasa Keuangan selaku otoritas terkait hendaknya bisa membangun hubungan lebih dengan pondok pesantren terutama Pondok Modern Asy-Syifa Balikpapan. Edukasi secara mendalam seperti ToT (Training of Trainer) yang biasa diadakan oleh OJK kepada guru-guru dapat membantu untuk memberikan pengetahuan yang lebih luas lagi terkait perbankan syariah.

\section{KESIMPULAN}

Berdasarkan hasil penelitian dan fakta-fakta yang telah dibahas pada bagian hasil penelitian dan pembahasan, dapat disimpulkan bahwa literasi keuangan syariah dewan guru Pondok Modern Asy-Syifa tergolong ke dalam less literate. Tergolong ke dalam less literate karena produk dan jasa yang diketahui oleh dewan guru hanyalah sebatas produk dan jasa yang mereka gunakan. Kurangnya sosialisasi dan edukasi tentang perbankan syariah merupakan salah satu hal yang menyebababkan literasi keuangan syariah, khususnya perbankan syariah di kalangan dewan guru Pondok Modern Asy-Syifa Balikpapan tergolong ke dalam less literate.

Adapun saran peneliti untuk berbagai pihak terhadap hasil penelitian ini adalah sebagai berikut:

1. Otoritas yang berwenang seperti OJK hendaknya melakukan kolaborasi dan atau kerjasama dengan lembaga keuangan syariah terutama perbankan syariah serta elemen masyarakat, organisasi dan komunitas, untuk melakukan sosialisasi dan edukasi keuangan syariah di pondok pesantren, khususnya pondok pesantren yang memiliki kredibilitas baik di daerahnya.

2. Saran bagi pondok pesantren hendaknya tidak menutup diri dari berbagai hal yang terkait dengan dunia industri jasa keuangan syariah, karena industri jasa keuangan syariah merupakan bagian dari penerapan (tathbiq) fiqh muamalah maaliyah.

Komunikasi yang baik kepada otoritas terkait dan lembaga keuangan syariah harus dibangun agar Pondok Modern Asy-Syifa dapat menjadi pondok pesantren yang dekat dengan industri jasa keuangan syariah dan menjadi agency perkembangan keuangan syariah. 
Muhammad Khozin. A: Literasi Keuangan Syariah...

3. Bagi peneliti selanjutnya, diharapkan untuk bisa menambah aspek yang lain seperti aspek keterampilan dan perlindungan konsumen. Dua aspek ini juga merupakan hal yang sangat penting dalam literasi keuangan syariah.

\section{PUSTAKA ACUAN}

Antonio, Syafi'i. (2015), Bank syariah: Dari teori ke praktik. Cet. ke-duapuluh. Jakarta: Gema Insani Press.

Aribawa, Dwitya. (2016), Pengaruh literasi keuangan terhadap kinerja dan keberlangsungan umkm di jawa tengah. Jurnal Siasat Bisnis, Vol. 20, No. 1, 1-13.

Ascarya. (2012), Akad dan produk bank syariah. Cet. ke-empat. Jakarta: Rajawali Pers.

Direktorat Informasi dan Edukasi Otoritas Jasa Keuangan. (2014), Strategi nasional literasi keuangan indonesia.

Direktorat Penelitian Kebijakan dan Pengaturan Edukasi dan Perlindungan Konsumen Otoritas Jasa Keuangan. (2016), Buku undang-undang Otoritas Jasa Keuangan dan regulasi edukasi dan perlindungan konsumen.

Direktorat Penelitian Kebijakan dan Pengaturan Edukasi dan Perlindungan Konsumen Otoritas Jasa Keuangan. (2016), Tanya jawab tentang Peraturan Otoritas Jasa Keuangan No.1/POJK.07/2013 Tentang Perlindungan Konsumen Sektor Jasa Keuangan dan Ketentuan Pelaksanaannya (Edisi ke-2).

Djibril, Muhammad. Di Indonesia, santri sonpes mencapai 3,65 juta. 10 Oktober 2016. www.republika.co.id.

Giesler, Markus, dan Veresiu, Ela. (2014), Creating the responsible consumer: Moralistic governance regimes and consumer subjectivity. Journal of Consumer Research, Vol. 41, No. 3, 840-857.

Hermansyah, Dadang. (2015), Pertumbuhan Bank Syariah Terhambat. 20 Mei 2017. www.koran-sindo.com.

Izzudin. (2015), OJK Tekankan Pentingnya Inklusi Keuangan di Pesantren. 20 Mei 2017. www.ekbis.sindonews.com.

Karim, Adiwarman. (2014), Bank Islam: Analisis fiqh dan keuangan (Ed. Ke-5). Jakarta: Rajawali Pers.

M Antara, Purnomo, Musa, Rosidah, dan Faridah, Hassan. (2016), Bridging islamic financial literacy and halal literacy: The way forward in halal ecosystem. Procedia Economic and Finance, Vol. 37, 196-202. 
Islamiconomic: Jurnal Ekonomi Islam

Vol.9 No.2 Juli - Desember 2018

Muhammad. (2004), Teknik perhitungan bagi hasil dan profit margin pada bank syariah. Yogyakarta: UII Press.

Nisaputra, Rezkiana. (2016), OJK yakin pangsa perbankan syariah sentuh 5,3\%. 12 Oktober 2016. www.infobanknews.com.

OJK. (2016). Kebijakan Inklusi Keuangan dalam Kerangka Regulasi Upaya Peningkatan Literasi dan Inklusi Keuangan. Sosialisasi Edukasi dan Perlindungan Konsumen.

POJK Nomor 76/POJK.07/2016 Tentang Peningkatan Literasi dan Inklusi Keuangan di Sektor Jasa Keuangan Bagi Konsumen dan/atau Masyarakat.

Rusmana, Oman, dan Ardianti, Lilis. (2014), Analisis perbedaan literasi keuangan masyarakat anggota credit union dengan anggota baitut tamwil.

Steenbrink, Karel A. (1991), Pesantren, madrasah, sekolah. Jakarta: LP3ES.

Subhan, Arief. (2012), Lembaga pendidikan Islam Indonesia abad ke-20: Pergumulan antara modernisasi dan identitas. Jakarta: Kencana.

Supriyatna, Iwan. (2016), Sistem Keuangan Digital Kembangkan Potensi Ekonomi Pondok Pesantren di Daerah. 20 Mei 2017. www.bisniskeuangan.kompas.com.

Syauqi Beik, Irfan dan Dwi Arsyianti, Laily. (2016), Ekonomi pembangunan syariah (Edisi revisi). Jakarta: Rajawali Pers.

Undang-Undang Nomor 21 Tahun 2008 tentang Perbankan Syariah.

Wawancara. 25 April 2017. Ruang Guru MI Asy-Syifa Balikpapan.

Wawancara. 27 April 2017. Kediaman KH. Abdurrahman Hasan.

Xiao, J. J., Ahn, S. Y., Serido, J., \& Shim, S. (2014), Earlier Financial Literacy and Later Financial Behaviour of College Students. International Journal of Consumer Studies, 38(6), 593 - 601.

Yasmadi. (2002), Modernisasi pesantren: Kritik Nurcholis Madjid terhadap pendidikan Islam tradisional. Jakarta: Ciputat Press.

Yusuf, A. Muri. (2014), Metode penelitian: Kuantitatif, kualitatif \& penelitian gabungan. Jakarta: Kencana. 